\title{
AIRBORNE FUNGI ISOLATED FROM FORTALEZA CITY, STATE OF CEARÁ, BRAZIL
}

\author{
Everardo Albuquerque MENEZES, Emerson C. Pereira TRINDADE, Maria Márcia COSTA, Caio César Furtado FREIRE,
} Márcio de Souza CAVALCANTE \& Francisco Afrânio CUNHA

\begin{abstract}
SUMMARY
Airbone fungi are considered important causes of allergic rhinitis and allergic asthma. The knowledge of these fungi in a city or region is important for the ecological diagnosis and specific treatment of allergic manifestations induced by inhalation of fungal allergens. The airborne fungi of Fortaleza, State of Ceará, Brazil, were studied during a one year period. Five hundred and twenty Petri dishes with Sabouraud dextrose agar medium were exposed at ten different locations in the city. The dishes exposed yielded one thousand and five hundred and twenty one colonies of twenty four genera. The most predominants were: Aspergillus (44.7\%), Penicillium (13.3\%), Curvularia (9.8\%), Cladosporium (6.8\%), Mycelia sterilia (6.0\%), Fusarium (3.5\%), Rhizopus (3.1\%), Drechslera (2.6\%), Alternaria (2.4\%) and Absidia (2.2\%). The results shown that Aspergillus, Penicillium, Mycelia sterilia, Fusarium and Alternaria were found during all months in the year. Absidia was more frequent during the dry season. Anemophilous fungi and the high concentration of spores in the air are important because may result in an increased number of people with allergic respiratory disease.
\end{abstract}

KEYWORDS: Airborne fungi; Allergic respiratory disease; Fungal allergens.

\section{INTRODUCTION}

There are multi-thousands of recognized species of fungi. They are found in soil, in water, on animals, on vegetation, in humans, and in almost every part of the environment. Anemophilous fungi are spread by the atmospheric air. Fungal spores are always present in the air, with rain and snow washing down most if not all spores from the air, and sunshine and wind cause an increase in the atmospheric distribution of such spores ${ }^{1}$.

Fungi are eukaryotic, filamentous and mostly spore-bearing organisms, which exist as saprophytes or as parasites of animals and plants. The development of allergies to fungi follows the same biological phenomena as allergies to other environmental allergens. Fungal spores are ubiquitous and the number of fungal species present in the environment is estimated to be at least one million. Some genera of airborne fungal spores such as Alternaria, Aspergillus and Cladosporium are found throughout the world. The airborne spores of these fungi are generally considered to be important causes of both allergic rhinitis and allergic asthma ${ }^{12}$.

Qualitative and quantitative knowledge of these fungi in a given region is of great importance and concerns because they can cause several respiratory diseases in man such as asthma and rhinitis when inhaled ${ }^{15}$.
Due to increasing awareness of the relationship of airborne fungi to allergy in patients suffering from asthma and rhinitis, many scientists and allergists began to study the presence and type of fungal spores in both indoor and outdoor air, using various collection methods. The most common procedure involves the use of microscope slide coated with petroleum jelly or silicone that is exposed to air for 24 hours. The fungal spores collected (as well as the pollens) are counted by the aid of microscope. To aid in identification of fungi, the culture plate exposure method (gravity method) was adopted routinely to study the number and type of fungi in the air ${ }^{1}$.

Although certain genera of fungi are common in urban areas, those that are specific to cities or regions may be important in terms of epidemiology and therapeutics. For the diagnosis of allergies and hyposensitizing treatments it is necessary to know the airborne mycota and differences between them ${ }^{8,9}$.

The expansion of the knowledge about the diversity of airborne fungi, besides increasing concern about potential allergenic microorganisms, and the search for new indicators of environmental pollution have been the main reasons for the existence of several studies of airborne fungi in Brazil $^{3,4,6,7,8,9,13,15,16,17,18,19,21}$.

The main purpose of this study was to determine the prevalence and 
seasonal variation of anemophilous fungi in the atmospheric air of Fortaleza - Ceará, in order to contribute to the knowledge of diversity of airborne fungi and distribution in the region.

\section{MATERIALS AND METHODS}

The city of Fortaleza is located on the East coast of the State of Ceará, Brazil, at latitude 3०43'2" South and longitude 38³2'35" West. According to Koppens' classification, Fortaleza's climate is tropical humid, with an average annual temperature between $26{ }^{\circ} \mathrm{C}$ and $28{ }^{\circ} \mathrm{C}$. Typically, there are two seasons, a rainy and a dry.

The rainy season extends from February through July, with slightly lower temperatures. During the rainy season of the year of study (1999), the following averages were recorded: precipitation, 1883.5 millimeters; barometric pressure, 1009.1 millibars; relative humidity, 83.5 percent; wind velocity, 2 meters/second and temperature, $26.8{ }^{\circ} \mathrm{C}$. During the dry season, which extends from August to January, the following averages were recorded: rainfall, 260 millimeters; barometric pressure, 1009.95 millibars; relative humidity, 74.7 percent; wind velocity, 3.1 meters/ second and temperature $27.3{ }^{\circ} \mathrm{C}$.

Ten locations of the city were selected for data collection: Cidade dos Funcionários (CF), Papicu (PP), Aldeota (AL), Centro (CE), Barra do Ceará (BC), Antônio Bezerra (AB), Parangaba (PA), Mondubim (MO), Rodolfo Teófilo (RT) and Fátima (BF). Every week during the year of 1999 (January to December), samples were collected using Petri dishes containing a medium of agar dextrose Sabouraud. With the exception of rainy days, these were exposed to the air for 15 minutes, at 1.5 meters above the ground. A total of 520 dishes were exposed.

After seven days at ambient temperature colonies were isolated in the same medium for the observation of formation of macrocolonies. Micromorphology was observed after microcultivation ${ }^{10}$, following RIDDEL $^{20}$ and the fungal strains were identified using the classifications of BARNETT \& HUNTER ${ }^{2}$, KREGER-van RIJ ${ }^{11}$ and McGINNIS et al. ${ }^{14}$.

Non-sporulating fungi were transferred to agar potatoes medium and kept at room temperature under white light, between 7 to 10 days, to sporulate.

\section{RESULTS}

The 520 dishes exposed yielded 1,521 colonies of 24 fungi. Nonsporulating strains were grouped in Mycelia sterilia. Table 1 shows the number of the colonies and frequency of each fungal genus in the city of Fortaleza and the ten collection sites. The ten most frequent airborne fungi isolated were: Aspergillus (44.7\%), Penicillium (13.3\%),

Table 1

Number of colonies and geographic distribution of different airborne fungal genera isolated in the city of Fortaleza at ten different sites

\begin{tabular}{|c|c|c|c|c|c|c|c|c|c|c|c|c|}
\hline \multirow[b]{2}{*}{ FUNGI } & \multicolumn{10}{|c|}{ SITES } & \multirow[b]{2}{*}{ No. of colonies } & \multirow[b]{2}{*}{$\%$} \\
\hline & $\mathrm{CE}$ & $\mathrm{AL}$ & $\mathrm{BF}$ & $\mathrm{AB}$ & $\mathrm{RT}$ & $\mathrm{CF}$ & $\mathrm{BC}$ & MO & PA & $\mathrm{PP}$ & & \\
\hline Aspergillus & 44 & 152 & 37 & 54 & 43 & 52 & 100 & 35 & 48 & 117 & 682 & 44.7 \\
\hline Penicillium & 13 & 52 & 22 & 18 & 15 & 15 & 27 & 12 & 18 & 12 & 204 & 13.3 \\
\hline Curvularia & 08 & 58 & 06 & 07 & 18 & 13 & 14 & 08 & 11 & 06 & 149 & 9.8 \\
\hline Cladosporium & 09 & 17 & 01 & 01 & 11 & 15 & 15 & 05 & 09 & 21 & 104 & 6.8 \\
\hline Mycelia sterilia & 04 & 02 & 15 & 22 & 08 & 09 & 07 & 09 & 08 & 08 & 92 & 6.0 \\
\hline Fusarium & 05 & 04 & 01 & 03 & 02 & 07 & - & 05 & 14 & 13 & 54 & 3.5 \\
\hline Rhizopus & 04 & 03 & 08 & 12 & 03 & 05 & 03 & 06 & 02 & 02 & 48 & 3.1 \\
\hline Drechslera & 03 & 08 & 03 & - & 05 & 03 & 02 & 03 & 03 & 07 & 37 & 2.6 \\
\hline Alternaria & - & 08 & 06 & 03 & 05 & 07 & 04 & - & 01 & 02 & 36 & 2.4 \\
\hline Absidia & 03 & 02 & - & 05 & 02 & 05 & - & 01 & 15 & - & 33 & 2.2 \\
\hline Neurospora & 02 & - & - & 02 & 02 & 06 & 02 & 02 & 05 & - & 21 & 1.4 \\
\hline Rhodotorula & - & 01 & 02 & 05 & 03 & - & 01 & 02 & - & - & 14 & 0.9 \\
\hline Aureobasidium & - & 01 & 02 & 02 & - & - & 02 & - & - & - & 07 & 0.5 \\
\hline Cunninghamella & - & - & - & - & 01 & - & - & 04 & 01 & - & 06 & 0.4 \\
\hline Mucor & - & - & - & - & 01 & 02 & - & 02 & 01 & - & 06 & 0.4 \\
\hline Epicoccum & - & - & - & 01 & 02 & - & - & 02 & 01 & - & 06 & 0.4 \\
\hline Syncephalastrum & 02 & 02 & - & - & - & - & - & 01 & 01 & - & 06 & 0.4 \\
\hline Paecilomyces & - & - & - & - & 01 & - & - & - & 03 & - & 04 & 0.3 \\
\hline Acremonium & - & - & - & - & - & 03 & - & - & - & - & 03 & 0.2 \\
\hline Nigrospora & - & - & - & - & 01 & - & - & 01 & - & - & 02 & 0.15 \\
\hline Verticillium & - & 01 & - & - & - & - & - & - & 01 & - & 02 & 0.15 \\
\hline Geotrichum & 01 & - & 01 & - & - & - & - & - & - & - & 02 & 0.15 \\
\hline Trichoderma & - & - & - & - & - & - & - & 01 & - & 01 & 02 & 0.15 \\
\hline Phoma & - & - & - & - & - & - & - & 01 & - & - & 01 & 0.10 \\
\hline TOTAL & 99 & 312 & 104 & 134 & 124 & 142 & 176 & 100 & 142 & 188 & 1521 & 100 \\
\hline
\end{tabular}

Sites of collection: CE - Centro; AL - Aldeota; BF - Bairro de Fátima; AB - Antônio Bezerra; RT - Rodolfo Teófilo; CF - Cidade dos Funcionários; BC - Barra do Ceará; MO - Mondubim; PA - Parangaba; PP - Papicu. 
Curvularia (9.8\%), Cladosporium (6.8\%), Mycelia sterilia (6.0\%), Fusarium (3.5\%), Rhizophus (3.1\%), Drechslera (2.6\%), Alternaria (2.4\%) and Absidia (2.2\%). In this work was verified that the Aspergillus is the genus most frequent with almost a half of airborne fungi colonies isolated in Fortaleza city (44.7\%).

In this study Phoma was isolated only in Mondubim (MO) and Acremonium only in Cidade dos Funcionários (CF). Trichoderma was isolated in Mondubim (MO) and Papicu (PP), Geotrichum in Centro (CE) and Fátima (BF), Verticillium in Aldeota (AL) and Parangaba (PA), Nigrospora in Rodolfo Teófilo (RT) and Mondubim (MO) and Paecilomyces in Rodolfo Teófilo (RT) and Parangaba (PA).

Table 2 shows the monthly distribution of each genus. The most frequent airborne fungi, Aspergillus, Penicillium, Mycelia sterilia, Fusarium and Alternaria were found all months during the year. Absidia was more frequent during dry season. Geotrichum and Nigrospora were isolated only in January, Phoma only in September and Verticillium only in August. Trichoderma was isolated in January and July and Acremonium in February and March. The remaining genera were randomly present throughout the year.

\section{DISCUSSION}

Fungal spores are ubiquitous constituents of both indoor and outdoor air samples. Some genera of airborne fungal spores such as Alternaria and Cladosporium are found throughout most of the world. Spores are generally considered to be important causes of both allergic rhinitis and allergic asthma; mould allergy, however, is the least understood and studied of the major forms of inhalant allergy ${ }^{1}$. In order to diagnose the presence of airborne fungi, several qualitative and quantitative techniques are used depending on the study place; in our study the airborne fungi spores were performed by the culture plate exposure method (gravity method). The 520 Petri dishes were exposed in the air.

Reports and surveys of airborne fungi from all parts of the world appear in the literature ${ }^{1}$. Among the airborne fungi that spread air spores and are important aeroallergens in the world are Aspergillus, Cladosporium, Alternaria, Penicillium and others ${ }^{1}$. These data are similar to those found in our work. The 520 Petri dishes exposed yielded 1,521 colonies of 24 fungi and the airborne fungi predominant in the air of the Fortaleza city were: Aspergillus (44.7\%), Penicillium (13.3\%), Curvularia (9.8\%), Cladosporium (6.8\%), Mycelia sterilia (6.0\%), Fusarium (3.5\%), Rhizophus (3.1\%), Drechslera (2.6\%), Alternaria (2.4\%) and Absidia (2.2\%) (Table 1).

Fungal spores are especially important in the tropics, in which climatic conditions are very favorable to the growth of fungi and may result in a high concentration of spores in the air, which in turn causes an increased incidence of allergic diseases ${ }^{1}$. In several countries Penicillium and Aspergillus had the higher concentration of spores $^{1}$, as in our study.

Table 2

Seasonal and monthly distribution and number of colonies of airborne fungi isolated in Fortaleza city

\begin{tabular}{|c|c|c|c|c|c|c|c|c|c|c|c|c|c|}
\hline \multirow[b]{2}{*}{ FUNGI } & \multicolumn{12}{|c|}{ MONTH } & \multirow[b]{2}{*}{ Total of the fung } \\
\hline & Jan & Feb & Mar & Apr & May & Jun & Jul & Aug & Sep & Oct & Nov & Dec & \\
\hline Aspergillus & 63 & 54 & 45 & 62 & 118 & 54 & 31 & 55 & 33 & 67 & 43 & 57 & 682 \\
\hline Penicillium & 29 & 16 & 25 & 13 & 19 & 20 & 16 & 04 & 09 & 15 & 19 & 19 & 204 \\
\hline Curvularia & 49 & 25 & 13 & 06 & 21 & 18 & - & 03 & - & 04 & - & 10 & 149 \\
\hline Cladosporium & 30 & 06 & 09 & 04 & 07 & 12 & 04 & 14 & 04 & 02 & - & 12 & 104 \\
\hline Mycelia sterilia & 05 & 04 & 11 & 11 & 10 & 08 & 06 & 06 & 07 & 12 & 04 & 08 & 92 \\
\hline Fusarium & 06 & 04 & 04 & 02 & 02 & 06 & 11 & 05 & 09 & 01 & 02 & 02 & 54 \\
\hline Rhizopus & 07 & 09 & 04 & 05 & 02 & - & - & - & - & 02 & 10 & 09 & 48 \\
\hline Drechslera & 06 & 05 & 01 & - & 02 & 01 & 02 & - & 02 & 04 & 07 & 07 & 37 \\
\hline Alternaria & 02 & 05 & 02 & 06 & 03 & 01 & 01 & 07 & 05 & 01 & 01 & 02 & 36 \\
\hline Absidia & - & - & - & - & - & 01 & 01 & - & 05 & 06 & 10 & 10 & 33 \\
\hline Neurospora & 04 & 02 & 01 & - & 01 & 02 & 06 & 05 & - & - & - & - & 21 \\
\hline Rhodotorula & - & - & - & - & - & - & - & - & 01 & 02 & 07 & 04 & 14 \\
\hline Aureobasidium & - & - & - & - & - & - & - & - & 01 & 06 & - & - & 07 \\
\hline Cunninghamella & 01 & - & - & - & - & 03 & 01 & 01 & - & - & - & - & 06 \\
\hline Mucor & 02 & 03 & - & 01 & - & - & - & - & - & - & - & - & 06 \\
\hline Epicoccum & 03 & - & 01 & - & - & 01 & 01 & - & - & - & - & - & 06 \\
\hline Syncephalastrum & - & - & 01 & - & - & 03 & - & 01 & 01 & - & - & - & 06 \\
\hline Paecilomyces & 01 & - & - & - & 03 & - & - & - & - & - & - & - & 04 \\
\hline Acremonium & - & 01 & 02 & - & - & - & - & - & - & - & - & - & 03 \\
\hline Nigrospora & 02 & - & - & - & - & - & - & - & - & - & - & - & 02 \\
\hline Verticillium & - & - & - & - & - & - & - & 02 & - & - & - & - & 02 \\
\hline Geotrichum & 02 & - & - & - & - & - & - & - & - & - & - & - & 02 \\
\hline Trichoderma & 01 & - & - & - & - & - & 01 & - & - & - & - & - & 02 \\
\hline Phoma & - & - & - & - & - & - & - & - & 01 & - & - & - & 01 \\
\hline TOTAL & 213 & 134 & 119 & 110 & 188 & 130 & 81 & 103 & 78 & 122 & 103 & 140 & 1521 \\
\hline
\end{tabular}


Most of the data on fungi collected in Brazil are originated from the South and Southeastern region of the country, where the climatic conditions differ greatly from the Northeast. Because of the climatic differences it becomes difficult to make seasonal comparison of the fungal genera common to different regions. PURCHIO et al. ${ }^{18,19}$, for example, observed a predominance of Cladosporium in the Baixada Santista area during the cold months. In Fortaleza this genus was isolated during the whole year, with predominance of colonies during the dry season (Table 2).

In a similar study MEZZARI et al..$^{15}$ revealed a prevalence of airborne fungi in Porto Alegre city, and the fungi most predominant found in the air of the city were: Cladosporium, Aspergillus, Penicillium, Curvularia, Alternaria, Fusarium and others. In our work similar results were also obtained, and the genera most frequently found in Fortaleza were the same identified in Porto Alegre city, despite of the climatic differences of the regions Northeast and South (Table 1).

SCHOENLEIN-CRUSIUS et al. ${ }^{21}$, in a similar study, found that the airborne fungi of Cubatão city, São Paulo state, air pollution caused by fertilizer industries, steel works, cement factories and chemical products industries, among others, was composed by 19 common, 10 rare and two constant fungal species, among the obtained fungi, at least 12 genera were reported as opportunistic fungi, 26 have been mentioned related to plant diseases and eight have been associated to respiratory allergy. Our work found fungi associated to allergic respiratory disease.

The genera most frequently found in Fortaleza were the same identified in other cities of Brazil: Aspergillus, Penicillium, Curvularia, Cladosporium, Mycelia sterilia, Fusarium, Rhizopus, Neurospora, Rhodotorula and Aureobasidium ${ }^{17}$. The continuous presence of spores of genera Aspergillus, Penicillium, Cladosporium and Curvularia alerts physician to the importance of continuously monitoring patients with allergies for these fungi.

Recife, Natal and Fortaleza are close and climatically identical cities. Aspergillus and Penicillium were more frequent in Fortaleza, Recife and Natal. Curvularia appear with most frequency only in Fortaleza. Mycelia sterilia is common in the three cities ${ }^{13,17}$.

In our study, 1,521 colonies of airborne fungi were detected and identified. Months from January through June, with slightly lower temperatures, shown a higher incidence of fungal spores with 894 colonies of the airborne fungi, and a lower incidence during the months of July (81 colonies) and September (78 colonies) (Table 2). September is a month dry and hot, in disagreement with BURGE et al. ${ }^{5}$, in San Francisco, that observed the higher prevalence of fungal spores during the dry and hot seasons. In our study, however, we did not measure the air humidity to verify this observation.

In the collections in Aldeota (AL) the greatest number of the airborne fungi genera was isolated (Table 1). Aldeota, an important economic region, nearly the sea, presents a low level of air pollution. In Centro (CE) was isolated a smaller number of airborne fungi, these results suggesting the existence of chemical pollutants that inhibit the sporulation of the fungi.

Therefore, the absence of significant differences in the number of colonies of fungi among the ten collection sites in Fortaleza suggests a low and homogeneous level of air pollution. This is probably linked to the small number of industries in the city and the fact that the existing ones are of the non-polluting types.

The occurrence of the great number of the allergenic fungal emphasizes the importance of the study of airborne fungi in Fortaleza. Fungal spores are especially important in the tropics, in which climate conditions are very favorable to the growth of fungi and may result in a high concentration of spores in the air, which in turn causes an increased incidence of allergic respiratory diseases.

\section{RESUMO}

\section{Fungos anemófilos isolados na cidade de Fortaleza, Estado do Ceará, Brasil}

Fungos anemófilos são importantes causas de rinite e asma alérgicas. O conhecimento destes fungos em uma cidade ou região é importante para o diagnóstico e tratamento específico de manifestações alérgicas provocadas por inalação destes alérgenos. Os fungos anemófilos da cidade de Fortaleza, Estado do Ceará, Brasil, foram estudados no período de um ano. Quinhentos e vinte placas de Petri com meio ágar Sabouraud destrose foram expostas em 10 diferentes locais na cidade. Nas placas expostas foram isoladas 1.521 colônias de 24 gêneros diferentes. Os mais predominantes foram: Aspergillus (44,7\%), Penicillium $(13,3 \%)$, Curvularia (9,8\%), Cladosporium (6,8\%), Mycelia sterilia (6,0\%), Fusarium (3,5\%), Rhizopus (3,1\%), Drechslera (2,6\%), Alternaria (2,4\%), e Absidia (2,2\%). Os resultados revelaram que Aspergillus, Penicillium, Mycelia sterilia, Fusarium and Alternaria foram encontrados durante todos os meses do ano. Absidia foi mais freqüente durante a fase seca e sem chuva. Os fungos anemófilos e a alta concentração de esporos no ar são importantes porque podem resultar em um aumento das doenças alérgicas do aparelho respiratório.

\section{ACKNOWLEDGEMENTS}

This work was supported by FUNCAP (Fundação Cearense de Apoio ao desenvolvimento científico e tecnológico) and UFC (Universidade Federal do Ceará).

\section{REFERENCES}

1. AL-DOORY, Y. \& DOMSON, J.F.- Mould allergy. Philadelphia, Lea \& Febiger, 1984.

2. BARNETT, H.L. \& HUNTER, B.B. - Illustrated genera of imperfect fungi. 3. ed. Minneapolis, Burgess, 1972.

3. BOHM, G.M.; SALDIVA, P.H.N.; PASQUALUCCI, C.A. et al. - Biological effects of air pollution in São Paulo and Cubatão. Environ. Res., 49: 208-216, 1989.

4. BUCK, N. \& GAMBALE, W. - Microbiota fúngica anemófila na cidade de Presidente Prudente, Estado de São Paulo, Brasil. Rev. Microbiol. (S. Paulo), 16: 9-14, 1985.

5. BURGE, H.A.; LEVETIN, E.; MUILENBERG, M.L. \& SOLOMON, W.R. - Fungus spore identification. San Francisco, American Academy of Allergy, Asthma \& Immunology, 1997.

6. FARIA, A. - Aspectos ecológicos e clínicos da flora anemófila de Belo Horizonte. Belo Horizonte, 1967. (Tese de Doutorado - Universidade Federal de Minas Gerais).

7. GAMBALE, W.; PURCHIO, A. \& CROCE, J. - Flora fúngica anemófila da grande São Paulo. Rev. Microbiol. (S. Paulo), 8: 74-79, 1977. 
8. GAMBAlE, W.; PURCHIO, A. \& PAUlA, C. R. - Periodicidade diária de fungos anemófilos na cidade de São Paulo, Brasil. Rev. Microbiol. (S. Paulo), 12: 176-181, 1981

9. GAMBALE, W.; PURCHIO, A. \& PAULA, C.R. - Influência de fatores abióticos na dispersão aérea de fungos na cidade de São Paulo, Brasil. Rev. Microbiol. (S. Paulo), 14: 204-214, 1983.

10. LACAZ, C.S.; PORTO, E.; MARTINS, J.E.C; HEINS-VACCARI, E.M. \& MELO, N.T. - Tratado de Micologia médica. 9. Ed. São Paulo, Sarvier, 2002.

11. KREGER-VAN RIJ, N.J.W. - The yeasts: a taxonomic study. 3. ed. Amsterdam, Elsevier Science Publishers, 1984.

12. KURUP, V.P; SHEN, H.D. \& BANERJEE, B. - Respiratory fungal allergy. Microbes Infect., 2: 1101-1110, 2000.

13. MACHADO, G.M.R. - Fungos anemófilos de áreas do grande Recife. Recife, 1979. (Dissertação de Mestrado - Universidade Federal de Pernambuco).

14. McGINNIS, M.R.; D'AMATO, R.F. \& LAND, G.A. - Pictorial handbook of medically important fungi and aerobic Actinomyces. New York, Praeger Special Studies, 1980.

15. MEZZARI, A.; PERIN, C.; SANTOS JÚNIOR, S.A. \& BERND, L.A.G. - Airborne fungi in the city of Porto Alegre, Rio Grande do Sul, Brazil. Rev. Inst. Med. trop. S. Paulo, 44: 269-272, 2002.
16. MOHOVIC, J.; GAMBALE, W. \& CROCE, J. - Cutaneous positivity in patients with respiratory allergies to 42 allergenic extracts of airborne fungi isolated in São Paulo, Brazil. Allergol. Immunopath., 16: 397-402, 1988

17. OLIVEIRA, M.T.B.; BRAZ, R.F.S. \& RIBEIRO, M.A.G. - Airborne fungi isolated from Natal, State of Rio Grande do Norte, Brazil. Rev. Microbiol. (S. Paulo), 24: 198$202,1993$.

18. PURCHIO, A.; GAMBALE, W.; PAULA, C.R.; UGOLINE, C. \& REMIE, C.A. - Airborne fungi of Baixada Santista, State of São Paulo, Brazil, Rev. Microbiol. (S. Paulo), 15: 258-265, 1984.

19. PURCHIO, A.; GAMBALE, W. \& PAULA, C.R. - Molds from some beaches in the southern area of São Paulo State (Baixada Santista), Brazil. Rev. Microbiol. (S. Paulo), 19: 166-171, 1989

20. RIDDEL, R.W. - Permanent stained mycological preparations obtained by slide culture. Mycologia, 42: 265, 1950

21. SCHOENLEIN-CRUSIUS, I.H.; TRUFEM, S.F.B.; GRANDEI, R.A.P.; MILANEZ, A.I \& PIRES-ZOTTARELLI, C.L.A. - Airborne fungi in the region of Cubatão, São Paulo state, Brazil. Braz. J. Microbiol., 32: 61-65, 2001.

Received: 18 June 2003

Accepted: 3 May 2004 